\title{
Corruption risks of private tutoring: case of Georgia
}

\author{
Nutsa Magda Kobakhidze \\ Faculty of Education, The University of Hong Kong, Hong Kong, China
}

(Received 4 July 2014; Final version received 15 August 2014)

\begin{abstract}
The paper focuses on teacher-supplied private tutoring in the context of post-Soviet Georgia, and elucidates the ways in which teacher-supplied private tutoring can be related to educational corruption. The paper draws on data from in-depth interviews of 18 school teachers in different parts of Georgia in 2013. The findings of the qualitative study indicate challenges that teachers face as a result of their dual lives between schools and private tutoring. The challenges include moral dilemmas related to tutoring their students. The paper discusses how private tutoring becomes a 'survival strategy' in the education system with low teacher pay, weak accountability system, and lack of monitoring efficacy. It highlights that the widely normalised practice in Georgia of teachers tutoring their students is not necessarily a form of corruption. However, it includes a high risk of corruption because of a thin line existing between teacher professional ethics and misconduct. Understanding how teachers rationalise tutoring their students contributes to the international research agenda by exploring teachers' perspectives on private tutoring, and offers insights into what constitutes teacher corruption in post-Soviet Georgia, making an important contribution to the international scholarship on educational corruption.
\end{abstract}

Keywords: teacher corruption; private tutoring; post-Soviet Georgia

\section{Introduction}

The relationship between private supplementary tutoring and educational corruption has been documented in different parts of the world (Biswal, 1999; Bray, 2003; Johnson, 2008; Dawson, 2009). High corruption risks are mainly associated with private tutoring when schoolteachers provide fee-charging tutoring, which Bray (2013, p.83) finds most vulnerable to corruption. Vulnerability here, by no means, indicates that all teacher-provided tutoring constitutes a form of corruption. It also does not suggest that teachers tutoring their students, for whom they are already responsible in public schools, are all corrupt. Branding these teachers as corrupt would humiliate many who are dedicated to their profession and who uphold high professional ethics, but for various reasons require extra income from private tutoring to survive. It would also be socio-culturally insensitive to suggest that all teachers who resort to tutoring are corrupt, because the context of a particular country shapes ethically acceptable and unacceptable practices based on cultural constructs and assumptions. Vulnerability here mostly refers to corruption risks, which increase in an unregulated tutoring market, where there is a thin line between teacher professional ethics and misconduct. Unfortunately, teacher corruption exists in different settings and, whether it is endemic or occasional, leads to the eroding of the professional credibility of teachers, hampers education quality in schools, increases socio-economic inequalities, and, in a broader sense, undermines public trust in the education system.

Although some studies have highlighted the ethical issues related to the widespread practice of teachers tutoring their students in Georgia (e.g. Matiashvili \& Kutateladze, 2006; International Institute of Education Policy, Planning and Management [EPPM], 2011), none of them have examined the phenomenon of teacher corruption in depth. Georgia is a unique case to investigate teacher corruption, because 69 percent of teachers are providers of

\footnotetext{
* Corresponding author. Email: nkobakhidze@gmail.com.
} 
tutoring, among whom many tutor their students (EPPM, 2011). There is no official regulation of any form of tutoring in Georgia, and the government remains silent regarding the phenomenon, which is likely due to teachers' low salaries in public schools. The only recommendation regarding private tutoring is included in the Teacher Professional Code of Ethics, which "discourages" teachers to tutor their students (National Center for Teacher Professional Development, 2010, p.5).

A recent Global Corruption Report by the Transparency International (2013) called for more research on educational corruption and remarked that most of the research "still focuses on the prevalence of the phenomenon and less on the causes or successful interventions" (p. xxiii). Perhaps scarcity of research on educational corruption is related to the sensitive nature of the topic, which poses difficulties to obtain reliable data and gain trust from research participants who may otherwise be sceptical about the confidentiality of their identities.

This paper focuses on teacher-supplied private tutoring in the context of post-Soviet Georgia, and elucidates the ways in which teacher-supplied tutoring can be related to educational corruption. Literature on educational corruption in Georgia, as well as in other post-Communist countries, has mostly been centred on corruption in the higher education admission system (see e.g. Temple \& Petrov, 2004; Silova, Būdienė \& Bray, 2006; Gabedava, 2013). MacWilliams (2002) reported that during the 1990s, professors from prestigious universities in Georgia, who knew the content of the entrance examinations, set high tutoring rates for students, and students and families were willing to pay, because this was an easy way to 'buy' access to higher education. The introduction of a centralised, transparent system of Unified National Examinations (UNE) in 2005 rooted out corruption in university admission examinations (World Bank, 2012a, p. 80). University professors lost control over entrance examinations and, consequently, since 2005, demand in university professors as popular suppliers of tutoring has dropped significantly. In contrast, schoolteachers have become major providers of tutoring as a cheaper and more convenient option for students.

Understanding how teachers rationalise tutoring their own students and what private tutoring means to them in the course of their professional lives contribute to the international research agenda by exploring teachers' perspectives on private tutoring, i.e., the supply side of the phenomenon that contrasts with much of the existing research, which focuses on the demand side. Further, the findings offer insights into what constitutes or what does not constitute teacher corruption in post-Soviet Georgia, which makes an important contribution to the international scholarship on educational corruption. The study is among the first to investigate the issue of teacher corruption from the perspectives of teachers in Georgia.

How common is teacher corruption in Georgia? What leads some teachers to be involved in corruption, while others in the similar socio-economic situation resist participating? What is the role of personal ethics versus "the system made me to do it" (Karklins, 2005. p. 2) excuse? This study attempts to illuminate understanding of some aspects of these questions. Teachers participating in this study cannot be portrayed as representatives of the national trends; however, drawing some observations and reflections are possible.

I will begin with setting the context for the Georgian education system and key reforms in the teacher profession that have shaped the current educational context. I will then situate the study in the conceptual framework that is informed by theories of corruption in education. The methodology section then explains the study design and provides details on participants, sampling, data collection, and analysis. Following the methodology section, I will demonstrate findings about different dimensions of teacher corruption and discuss teachers' own rationalisation of the phenomenon. An analysis of findings in relation to the theoretical literature concludes the paper.

\section{Background}

Located at the crossroads between Europe and Asia, Georgia has undergone an intensive process of transformation from a Soviet republic into a modern democratic state. Similar to 
other countries in the Caucasus, the post-Soviet transformation period was marked by a collapse of national economy and hyperinflation (World Bank, 2012a). It is estimated that the cumulative decline in Gross Domestic Product (GDP) in Georgia was more than $70 \%$ between 1990 and 1994 (Global Edge, 2013). Public expenditure on education declined from over seven percent of GDP in 1991 to below one percent of GDP in 1994 (Matiashvili \& Kutateladze, 2006). However, since 2004 Georgia's economy has witnessed a steady growth due to foreign direct investments, robust government spending, and public administration reforms (Central Intelligence Agency, 2013).

The 'Revolution of Roses'1 in 2003 brought strong political leaders in power who initiated rapid economic, political, and education reforms in Georgia. Anti-corruption policy across all governance levels became the hallmark of that period. Transparency International's Global Corruption Barometer ranked the country first globally for the relative eradication of corruption and second for effectiveness of government fighting against corruption (World Bank, 2012a).

In 2001, the World Bank and the Government of Georgia signed an agreement to allocate long-term credit to the education sector amounting to US\$60 million (World Bank, 2001). The program Education System Realignment and Enhancement Program was the first comprehensive education plan in Georgia after the collapse of the Soviet Union, which shaped the Georgian education system through radical transformations between 2004 and 2011.

\section{Teacher salaries and major reforms in teaching profession}

Since the collapse of the Soviet Union ${ }^{2}$ every consecutive government in Georgia has stressed the importance of teachers in fostering new generations and thus, placed teacher quality high on the national agenda. However, major teacher-related reforms were delayed, while other education reforms (such as school decentralisation, voucherisation, student-centred pedagogy) were given priority. Like many other reforms in Georgia, teacher policies were designed according to the abovementioned World Bank project. The overall cost of the teacher professional development component sponsored by the World Bank's project amounted to US\$1.62 million between 2004 and 2011 (World Bank, 2012b).

The teaching profession was not regulated in Georgia until 2010 when the Ministry of Education and Science (MoES) administered the first teacher certification examinations (TCE) aiming at professionalising and regulating the teaching profession. It was believed by the general public that teacher certification would improve teacher quality in schools and significantly raise teacher salaries for certified teachers. The studies that investigated teacher attitudes toward certification examinations noted that TCEs did not meet the needs of teachers either professionally or financially (Institute for Social Studies and Analysis [ISSA], 2012; Kobakhidze, 2013). Hence, private tutoring is still considered as the main source of salary supplement to teachers. In 2008, ISSA conducted an empirical study on teacher supply and demand in Georgia and surveyed 4,000 teachers nationwide. According to the study, 67 percent of teachers were ready to leave the profession if better conditions were offered elsewhere (ISSA, 2008).

Since 1990 and onwards, teachers' salaries have been under or close to the subsistence level $^{3}$, though they have gradually increased since 2005. In 2013, teachers' basic salary increased from 245 GEL ( US\$140) up to 305 GEL ( US\$175), but minimum living expenses also rose and became 252.7 GEL ( US\$145) (GeoStat, 2014; MoES, 2013). Teacher's basic salary, as defined by the MoES, indicates that a teacher teaches full time, i.e. eighteen hours per week. However, quite a significant number of teachers do not have a full teaching workload, which means that teachers may have as low salaries as 50 GEL ( US\$29), or 80 GEL ( US\$46) per month, much less than half of the subsistence level.

The teacher de-professionalisation process examined in the teacher literature (e.g. Ginsburg \& Megahed, 2009) echoes the developments that have occurred with regard to the teaching profession in Georgia. Since gaining independence, the dominant discourse on 
teacher professionalism in Georgia has been that teachers are unqualified and lack professional training. For example, in recent years, the media has often portrayed Georgian teachers' image as an unqualified professional force, citing their individual failures from teacher certification examinations. From a highly esteemed occupation during the Soviet times, the teaching profession has been downgraded to a socially inferior status. Some scholars viewed private tutoring as an opportunity for teachers not only to generate extra income, but also as a space where they can reclaim the lost professional identity and autonomy in the post-Soviet context (Popa, 2007). Other studies also highlight the benefits that teachers can gain from private tutoring practice beyond the financial gain, such as professional satisfaction and professional fulfilment (Soldo \& Jokić, 2013, p. 154).

An earlier cross-national study revealed that tutoring consumption was one of the highest in Georgia among other countries of the post-Soviet region (Matiashvili \& Kutateladze, 2006, p. 197). As reported by the sampled university students, 79.7 percent of them used some kind of tutoring during the university exam preparation process (Matiashvili \& Kutateladze, 2006). The most recent survey on private tutoring conducted in Georgia found that every fourth student in Grades 2 through 12 takes private tutoring lessons, with 57 percent among Grade 12 students (EPPM, 2011, p. 25). Drivers of demand and supply of tutoring reinforce each other, among which perceived low quality of school education and teachers' low pay play significant roles. Poor socio-economic conditions offered to teachers over the past decade resulted in declining professional legitimacy of teachers (Silova et al., 2006), which in turn forced them to seek personal survival through private tutoring.

\section{Conceptual Framework}

The phenomenon of corruption is old and can be traced back to remote human history (see e.g. on the Roman Empire in Rothstein \& Torsello, 2013, p.5; or Muslim or Chinese cultural traditions in Alatas, 1968, pp. 7-10). What have mainly changed are its forms and aspects. In a globalised world, corruption has become more sophisticated, which makes it harder to study it empirically, because it does not allow for direct observation and is shrouded in secrecy (Nowak, 1996, p. 1; Alatas, 1968, p.1). Another challenge in researching corruption theoretically is related to its definition: there is no universal agreement on what constitutes corruption, because its definition differs from country to country and, perhaps, from individual to individual. The problem, however, is not an absence of a definition but rather an abundance of it (Kostadinova, 2012, p. 6). A widely used definition of corruption is "the misuse of public power for private gain” (Karklins, 2005, p. 4), or as Transparency International (2013, p.xx) defines it, "the abuse of entrusted power for private gain”. One of the earlier definitions of corruption is found in sociology, which looks at the phenomenon of how different social actors perceive it. Based on this understanding, Heidenheimer (1970, p. 24) differentiated three types of corruption, "black corruption”, "white corruption”, and "grey corruption". This typology highlights the level of condemnation and/or level of acceptance of practice by elites and masses, and emphasises that degree of corruption varies, as does its acceptance. The legal approach to corruption sees it as a break of rules/laws, but so-called "public good" or "public opinion" approaches see the phenomenon as a breach of ethics (Karklins, 2005, p. 4). Klitgaard, a prominent corruption scholar, defined corruption as a situation when a person "illicitly puts personal interests above those of the people and ideals he or she pledges to serve" (as cited in Karklins, 2005, p. 4).

The difficulty of having a consensus in understanding corruption is mainly related to cultural relativism. What is considered corruption in one culture can be socially accepted in another. Opponents of the cultural relativist approach often argue that "culture" often has been used "to explain, or excuse, acts of corruption" and this constitutes another type of Western naiveté when studying non-Western societies (Larmour, 2008, p. 225). RoseAckerman (1999) is in favour of an economic approach to understanding corruption, and states that although cultural differences and moral aspects provide some understanding of corruption, there are basic values that exist across cultures. After analysing multiple samples 
of ethnographic material on indigenous societies, Rothstein and Torsello (2013) also concluded that in different cultures, corruption is understood in a similar manner. The authors suggest that the differences in understanding do not necessarily relate to different moral understanding in society but to "how different societies come to understand and value the difference between public and private goods” (p. 22).

Debates continue as to what extent the definition of "misuse of public power for private gain" is culturally neutral. While Karklins (2005, p.5) argued that this definition is universal, because it is a core meaning of the concept, Ledeneva (2009, p.72) noted that this definition is neither culturally nor historically neutral regarding post-communist countries because, she argued, corruption cases are "new and interesting hybrids of communist and post-communist forms of exchange that may not add up to 'market democracy' or 'capitalism'”, but must be understood first and foremost on their own terms. Karklins (2005) studied the nature of postcommunist corruption and identified 'the system made me do it' effect when a postcommunist citizen excuses his involvement in corruption. She called a post-communist country paradox when most people reject it and yet participate in it (Karklins, 2005, p.7). In this situation, corruption is understood as a "collective action" and it becomes a rule of the game when rebellion against it would not change society for any better (Rothstein \& Torsello, 2013, p. 5). Despite many scholarly attempts to define and conceptualise corruption in different parts of the world, conceptual ambiguities still remain and require further scrutiny.

Different appearances of corruption in the education sector is considered harmful not only for an education system but for society at large. Corruption in education may permeate all levels of education, and can be an umbrella term for a wide range of activities and behaviours, such as fake diplomas, purchasing grades, fake accreditation agencies, teacher corruption, giving out exam items, 'degree mills', nepotism and favouritism in university admissions, among others.

\section{Teacher corruption}

In the context of private tutoring, Bray (2003, p.27) defines teacher corruption as a practice when a teacher abuses his or her position over the students. Teacher corruption manifests itself in different forms of teacher misbehaviours, such as teacher absenteeism, gift giving to teachers, teacher recommendation, and informal payments to teachers. Teacher absenteeism, when the teacher is illegitimately away from the classroom, has been documented in Ecuador (53\% absenteeism rate), Uganda (27\% absenteeism rate), and Cameroon where the absenteeism rate is 15 percent (Ngwe, 2013, p. 75; Patrinos, 2013, pp. 70-71). Teacher absenteeism is metaphorically called moonlighting, which refers to the situation when teachers work elsewhere and not where they are scheduled to teach (see e.g. Patrinos, 2013, p. 70).

Similar to moonlighting, gift giving to teachers is considered a significant problem in many countries, while in others it is accepted as a social norm. Although cultures differ in determining whether gift giving is a form of corruption or social norm, evidence suggests that in all cultures there is a certain threshold of acceptance after which gift giving becomes a problem. Yang (2012) reported that in China some teachers expect expensive gifts during the Teacher Appreciation Day; some gifts include designer watches or even cash. In line with Yang (2012), Wan (2013) referring to the same country, China, remarked that "from admission to grades to teacher recommendations, it is negotiable in Chinese schools if you know the right person or have enough cash" (Wan, 2013). It seems that different forms of teacher corruption are not completely unknown to the developed world. For example, Barret (2014) reported that in fee-paying schools in London, teachers accept very expensive gifts from parents, such as designer handbags, diamond necklaces and even cash. Some of the gifts constitute the so-called 'class gift' given to teachers at the end of each term (Barret, 2014). In contrast, gifts to teachers during Teachers' Day or parent conferences to show gratitude is considered socially acceptable in South Korea. The Korean Supreme Court endorses holiday gifts and gratitude gifts to teachers (Chonji) as ‘social courtesy exception' and are not a bribe 
only "if the amount does not exceed the socially acceptable level and are not directly related to public officials' actions to favour the giver" (Ko, Cho \& Lee, 2012, p. 8). While these observations highlight the cultural nuances of the way corruption is understood, they also point out the degrees of corruption or certain norms and tolerance thresholds.

A few studies also reported bribes accepted by teachers for high marks and teachers forcing students to take private tutoring in some countries in Central and Eastern Europe and the former Soviet Union, such as Russia, Ukraine and Uzbekistan (see e.g. Klugman, Micklewright \& Redmond, 2001, p. 6), Albania (see e.g. Tsakonas, 2002, p. 40), Bosnia and Herzegovina (Transparency International Bosnia and Herzegovina, 2013, p. 190), Kazakhstan, Kyrgyzstan and Tajikistan (Silova, 2009, p. 87). Milovanovitch (2014, p.376) referred to these types of teacher malpractice as a "soft" form of corruption, which in the axis of tolerance occupies the middle point between corruption offence and acceptable practices. Johnson (2008, p.193) identified teacher corruption in Kyrgyzstan as "grey", that is a practice tolerated by some citizens but condemned by others.

A recent Education for All (EFA) Global Monitoring Report (GMR) (UNESCO, 2014) discusses teacher-supplied tutoring and associated corruption risks by referencing to cases from Cambodia and Egypt. In those countries, some teachers tend to generate demand for tutoring by deliberately omitting parts of the national curriculum (p. 271). In general, the poorly functioning school system and low remuneration of teachers are considered reinforcements of teacher-supplied tutoring (UNESCO, 2014, p. 32). The report further comments that when teachers are engaged in tutoring their students, this reinforces social inequalities since the "poorest students suffer most, because their families cannot afford tutoring” (p. 303). The GMR links private tutoring to poor teacher governance and calls for stronger managerial policies that will ensure that teachers deliver the entire curriculum in the classroom and devote their time to teaching in public schools.

Some scholars have contested the labelling of private tutoring as teacher corruption and instead re-conceptualised it as a survival mechanism. In the context of Cambodia, Dawson (2009) explored teacher corruption and linked it to the teachers' inadequate salaries from public schools. The author noted that some teachers would live in poverty if they relied only on income from the government schools. On this ground, the author refers to teachers' tutoring practice as "forced corruption" and problematised "the characterisation of the practice as 'corruption' with consideration toward the grossly inadequate income of state teachers and the problems inherent with curriculum time, content, and teaching methods in the system" (Dawson, 2009, p.71). Moreover, the widespread practice of so-called "tricks of the teacher" in Cambodia has been used to refer to the situation when teachers withhold a curriculum or slow down the instruction to attract private students (Dawson, 2009, p.72).

In the same context of Cambodia, Brehm, Silova and Tuot (2012, p.14) discussed corruption issues and remarked that it is difficult to label a situation as education corruption when teachers provide tutoring to their students. Johnson (2008, p.213), who explored teacher corruption in Kyrgyzstan, made similar comments and noted that teacher corruption "is justified by the low pay and inadequate support teachers are perceived to receive," and the general public often blames the government or economy of their country rather than teachers for being engaged in corruption. Statements made by Dawson (2009), Johnson (2008) and Brehm et al. (2012) are in line with Rose-Ackerman (1999, p.72) who referred to corruption as "a survival strategy" in the context where a public sector pay is very low. This indicates that the educational system's failure to provide sufficient salaries to teachers leads teachers to moral weakness. It also indicates that not all teachers are 'led' by the system, further signalling the importance of a moral dimension here. If one follows the system's failure argument that personal ethical integrity is completely removed from the context, then the argument 'the system made me do it' can justify any form of corruption and misconduct.

Bray (2013) suggested that in order to avoid corruption cases, it is better to prohibit teachers tutoring students; however, if it is already rooted in the system, then public campaigns against corruption may be a good idea to mobilise public attention (p. 85). Bray also acknowledged that prohibiting teachers from tutoring in countries with low teacher pay might not be an effective strategy. It could also lead teachers to, for example, a "system of 
referrals" or an exodus of the shadow education sector (p. 85). Other scholars take a more extreme view and call for punishing teachers for engaging in private tutoring. For example, Heyneman (2011, p.186) defined teachers tutoring their students as a practice that is "contrary to the professional standards of educators," and therefore, advised that such teachers "should be punished with a fine and/or loss of teaching license". Meir and Friedrich Ebert Foundation (2013, p.69) made similar remarks in the wider context of teacher corruption when they identified two underlying causes of teacher corruption: lack of supervision and lack of sanctions against the misconduct. Some scholars relate teacher corruption to the system of weak monitoring mechanisms. For example, Biswal (1999, p.238), who studied teacher corruption in developing countries, noted that the main reasons for teacher-supplied tutoring are related to 1) low salaries from government schools and 2) weak accountability and monitoring system. Biswal further argued that governments in developing countries delegate their responsibility to provide sufficient salaries to teachers, who, in turn, offer fee-based tutoring to students (1999). This situation is closely related to the simple formula offered by Klitgaard (1988), according to which "corruption = monopoly + discretion - accountability" (as cited in Bray, 2003, p. 28).

The above literature review demonstrates that there are at least four distinct approaches in the literature as what constitutes teacher corruption. Authors, such as Johnson (2008), Dawson (2009), Brehm et al. (2012) take a soft approach and attempt to relate teacher corruption to economic circumstances, for example, teacher underpay. This approach can be categorised as a 'survival strategy' approach. Heyneman (2011) and Meir et al. (2013) have a more disciplinary approach and talk about sanctions against teachers, which signify a 'punitive approach'. Biswal (1999) directs the discussion toward accountability and monitoring of a school system. This might be called a 'monitoring approach'. Bray (2013) suggests that governments should prohibit teachers tutoring own students. However, in societies where teacher salaries are low and the practice is widespread, regulations may fail; therefore, public campaigns could be a more pragmatic policy choice. This is a 'regulatory approach'.

\section{Methodology}

The methodological design of this study was qualitative, which helps to better understand the context and produce rich and in-depth data on the phenomenon (Berg, 2009). The choice of the research methods was also informed by the nature of the research questions of a bigger project, which aimed at investigating how 1) Georgian teachers perceived and responded to social, educational, and economic aspects of private tutoring; and 2) how private tutoring affected teachers' professional lives. This article is focused only on the theme of how teachers rationalise tutoring their students and what private tutoring means to them in the course of their professional lives. The sensitivity of the topic required additional time to build trust and establish rapport. I had casual conversations with the participants before the actual interviews, which in some cases lasted longer than interviews themselves and contributed significantly to gaining trust. On average, interviews with teachers lasted about an hour and included openended questions related to their past and present experiences of private tutoring and mainstream schooling. Pre-interview preparation also included getting familiar with teacherrelated policies and practices in the country, reading and analysing policy statements, latest amendments to the laws, statistical data from teacher certification exams, teacher professional development updated schemes, and media and NGO reports on issues referring to teachers.

Notwithstanding the preliminary preparations, I faced challenges in recruiting and engaging participants. For example, some teachers in the capital were reluctant to be interviewed after hearing that the research was about private tutoring, but seemed willing to participate in the general interview on other educational matters. Some participant teachers frequently paused interviews when conversation referred to the most sensitive issues, such as tutoring own students, the income they received from tutoring, the impact of tutoring on teachers' relationships, among other issues. I employed different probing techniques, such as 
echo probing, silent probing, or "tell me more" probes (Bernard \& Ryan, 2010, pp. 31-32). The interview time with an individual teacher varied from one hour to two hours at a convenient place for the participant. Various informal conversations with the teachers who declined to be interviewed helped me better understand the social reality as perceived by the teachers. Data from field notes from every site of research formed another essential component of the whole research data.

Snowball sampling and maximum variation sampling techniques in combination were used to recruit 18 schoolteachers (Creswell, 2007). Choosing a maximum variation sampling allowed me to recruit participants with a wide range of experiences related to private tutoring. Teachers of both public and private schools from East, West and South of Georgia (total number 14) as well as four teachers from the capital, Tbilisi, took part in the study. The geographical coverage of the study included three districts of Tbilisi and four regional towns and four villages among which one was a mountainous village. Taking into consideration that the teaching profession is highly feminised ${ }^{4}$ in Georgia, the majority of the study participants (total number 17) were female. Teachers of Mathematics, Georgian language, English, Biology, Chemistry, History, Physics, and the Russian Language teaching at all three levels of education (primary, lower secondary and upper secondary) participated in the study. The participants' age ranged from 23 to 64 years, but most of them were in the 50-59 age category. The teaching experience also varied greatly and ranged from 2 to 45 years. Teachers differed in terms of their engagement in private tutoring practices: some became tutors for about one year before the interview, while others started tutoring about 40 years ago. The majority of teachers held BA degrees, four teachers had MA degrees, and one held a PhD degree. About half of the participant teachers (9 teachers) were certified; some (4 teachers) had passed only one certification examination, while the rest were uncertified. This diverse approach to selecting research participants helped identify commonalities and differences in teacher experiences across three regions and the capital, and allowed the researcher to achieve some degree of representativeness.

The study took place over two and half months in summer 2013 in different parts of Georgia. During the first phase of the research (July to mid-August), I conducted interviews with participants from the regions, while in the second phase, I gathered data from the capital, Tbilisi (mid-August to mid-September). The main instrument of the study was a semistructured interview with an interview guide consisting of multiple open-ended questions (Bernard, 1988, p. 205). The semi-structured interview guide allowed the researcher to stay within a designed scope of investigation, while striving to achieve an in-depth understanding of the participants' perceptions related to the phenomenon (Berg, 2009, p. 110). Data analysis coalesced with the data collection process. I wrote field-notes and reflective memos while in the field. Later, the data from the interviews were transcribed and translated from Georgian into English and entered into NVivo software for coding. The coding process evolved though a) coconstructing inductive codes in the process of data analysis, and b) creating deductive codes based on the theoretical understanding (Bernard \& Ryan, 2010, p. 55). By searching for similarities and differences across units of data, codes were merged into categories and relationships between categories were established. The categories were consolidated into important themes and supported with direct quotations from the participants. This paper focuses on ethical (corruption risks), social (relationships), and educational (teaching and learning) dimensions of data; however, much of the data gathered represent the economic aspects of private tutoring, which is out of the scope of the present paper.

\section{Findings}

\section{Motivation for tutoring and its impact on teacher instruction}

Almost all interviewed teachers confirmed that, at the time of the interviews, they were tutoring their students. Tutoring provided by the teachers usually takes place in teachers' homes. Teachers used terms like "teaching at school" and "teaching at home" to differentiate between school and private tutoring. 
All teachers named the financial motive as the number one reason behind tutoring their students. Among the benefits of tutoring, teachers mentioned two main reasons: (a) tutoring deepens teacher professionalism; private practice requires teachers to learn more in their profession, look for new teaching materials, which helps them be better professionals; (b) tutoring brings professional satisfaction and enjoyment; many teachers commented that they love working with pupils and enjoy the 'fruits' of their work when their students become successful in life.

Except for one teacher, all of them highlighted the complexity of being a teacher and a tutor at the same time. Some found it difficult to conceptualise their professional roles between two parallel education systems. For them, the most challenging was the time pressure from having two parallel jobs. Some of them shared candid accounts of how they prioritised tutoring over school teaching and put more energy and effort in private practice, because they gained financially from tutoring. Sometimes teachers deliberately reduced their school workload to have more time for private students. The following comment reflects this attitude: "Many teachers try to have less workload in schools to save their energy for private tutoring...so the main focus has shifted from schools to tutoring” (Teacher C).

But at the same time working in school was viewed as important to attract private students, who would otherwise find a different teacher. Teachers were committed to maintaining their school job, because the income from public schools, although meagre, was stable compared to tutoring on demand.

One of the negative effects tutoring had on the quality of instruction in the public schools was further evidenced by the lack of teacher preparedness for classroom teaching with no lesson plan ready. One teacher shared her experience of being physically tired, "The reality is that after tutoring many students, a teacher is tired and has no time to prepare for the next day's teaching in school” (Teacher F). Many teachers echoed the same sentiment, which is indicative of how private tutoring affects some teachers' quality of instruction in schools.

\section{Benefits of tutoring for teachers}

Among the positive aspects of tutoring, the teachers mentioned that helping students was a good practice, which was beneficial for their educational and career advancement. The teachers had felt a sense of pride when their private students were successful in national examinations. However, when talking specifically about the positive aspects of tutoring their students, teachers struggled to find good reasons. For example, one teacher mentioned how tutoring her students raised the student's motivation to learn:

I know the strengths and weaknesses of the students whom I teach at school very well. I know how to teach them effectively at home. Students are more motivated when the same curriculum is covered by the same teacher twice. (Teacher B)

This teacher was among the very few who reasoned that tutoring one's own students is beneficial for students' learning. Other motives that almost all the teachers mentioned were to provide free tutoring for students of relatives, friends, colleagues and those, who came from economically disadvantaged backgrounds.

\section{Robin Hood Teachers ${ }^{6}$}

All teachers reported that they almost always had one or more so-called 'free-students' (i.e. non-fee paying students). One teacher called this service "philanthropy" (Teacher J), and another referred to it as "my present to a student" (Teacher A). They also mentioned that often parents of 'free students' tried to compensate with other means, such as gifts. One teacher highlighted that she absolved herself of guilt stemming from tutoring her students by having 'free students'. According to her, she 'redeems' herself by offering tutoring for free to her students. Often, teachers mix 'free students' with fee-paying students in tutoring groups, 
and thus, the cost of tutoring is covered only by some of them. This signifies that teachers offer free classes 'at the expense' of fee-paying students.

The phenomenon of free tutoring is another dimension of shadow education, which needs further research. The scale of this phenomenon as well as reasons behind free tutoring varies across cultures. For example, data collected by the author of this paper in Georgia in 2011 through the national component of TIMSS (Trends in International Mathematics and Science Study) \& PIRLS (Progress in International Reading Literacy Study) studies showed that 16.3 percent of Grade 8 students received free tutoring. The scale of free tutoring on Grade 4 was even higher and constituted 38.13 percent.

\section{Corruption risks}

Among all the questions posed to teachers, the most sensitive topic appeared to be corruption risks associated with tutoring students. During the interviews, the respondent teachers recounted stories of teachers' misconduct that they had heard about, but often avoided to mention their own schools ${ }^{7}$. Corruption-related practices based on teachers' perceptions can be categorised in two groups. This classification has implications for the direction and orientation of corruption: whether corruption is client-initiated (demand side) or providerinitiated (supplier side).

\section{Client-initiated corruption}

On the side of client-initiated corruption, teachers mentioned that some parents purposefully sent their children to their teachers, directly or indirectly requested high marks and/or disclosure of exam items, and thus, benefited from favouritism. One teacher recalled a case when the parent begged her to accept her son as a tutee, and after several trips to her home, the teacher finally agreed to tutor him. She stated that the student had an expectation of having exam answers in advance, "Then I noticed that the student looked at me differently during lessons... I realised lately that this look meant that I disappointed him by not giving out exam tests in advance" (Teacher R).

Another teacher echoed the same expectations coming from their students in the following comment, "A student often wants to receive tutoring from their own teacher, because he/she wants a good mark from her" (Teacher M).

\section{Provider-initiated corruption}

The provider-initiated corruption cases that the interviewed teachers reported varied. They included 'forced tutoring' - when teachers persistently deflated marks to coerce students to seek tutoring from them. A similar misconduct was reported when a teacher inflated marks of her private students, paid more attention to them, and neglected other students. This is a marketing strategy of some teachers to attract more students. The following quote from one rural school teacher is a good illustration of this, "I have heard of teachers who purposefully deflate marks, because students do not receive tutoring from them...In this way, they try to attract more students” (Teacher $\mathrm{N}$ ).

One teacher with a long-time tutoring and teaching experience remarked, "Why would a teacher give high marks to a student, whom she tutors at home? Because by doing that, she shows the parents the effectiveness of tutoring” (Teacher $\mathrm{H}$ ). Another teacher rationalised why teachers were tempted to inflate marks of their private students:

There are many risks associated with tutoring their own students...but sometimes we teachers do not have another choice. When you tutor your own student who does not study well at school and you give the deserved low mark, you are destroying your authority... They would blame you that you have not taught him/her well...You have to give high marks...regardless of what you think, you are involved in this game.... (Teacher M). 
Another form of attracting students was to simply persuade parents that students urgently needed tutoring. One informant said: "Some teachers explicitly complain with parents why they have sent their kids to another teacher and not to her".

One of the most unacceptable teacher behaviours, as interviewed teachers reported, was a case when a teacher disclosed school test items with their private students in advance. Many expressed concerns with regard to this malpractice. For example, one teacher noted, "Some teachers train their private students in school tests in advance at home, so their tutees outperform others on school exams. I hate this” (Teacher G). In Georgia, most of the school exams until the final grades are designed by teachers and are not nationally standardised; therefore, teachers have the 'power' to control the content of tests, which opens the door to corrupt behaviour.

\section{Relationships dimension}

Some of the interviewed teachers highlighted a 'student referral system' during which the same subject teachers exchange private students by recommending each other. The practice that had also existed in the Soviet times creates discomfort for some teachers. "Does my child need private tutoring?" is a very common question that parents often ask teachers. This topic was among the most sensitive topics for teachers during interviews, because it is linked to both 'forced tutoring' and the 'referral system'. The following statement by one teacher is an illustration of this point:

I recommend tutoring in my subject only if I know a parent well in person, so I am sure she will not interpret my words differently... I never indicate a particular teacher. It would mean that I send students to my friends (Teacher P).

Another teacher recalled a situation when she regretted her words, "Once I told a parent that a child needed extra help. She turned to me and asked if I am willing to tutor. I realised that I sounded that way and clarified that I never tutor my own students” (Teacher N).

These comments demonstrate that the tutoring issue can complicate relationships between teachers and parents, which sometime may include pressure. The phenomenon has impact on relationships between parents and teachers, between teachers and students, and among teachers, too. Some teachers openly resist participating in unethical practices but, in turn, receive anger from colleagues. For example, one young teacher recalled a situation when a colleague teacher requested that she change a mark for her private student: "This was an illegal request...I did not do it, which has negatively affected my relationship with her," Teacher D remarked.

In contrast, other teachers did not consider changing marks for reasons of loyalty to family, friends, colleagues, and relatives as problematic. For example, Teacher K candidly said that it is difficult "to grade friends' children objectively" and "it is okay to inflate marks a little bit.” It seems that social relations sometimes stand above 'objectivity'. Put differently, changing marks for the sake of one's friendship or kinship was considered as acceptable by teachers, while changing marks for money, i.e. fee-based private tutoring was considered as unethical.

The continuum model of teacher corruption in Figure 1 demonstrates acceptable levels of corruption in Georgia as perceived by teachers. Teachers' opinions about raising marks for the sake of kinship/friendship as an ethical behaviour refer to the cultural understandings of what is acceptable and what is not in Georgia as perceived by the interviewed teachers. The 'student referral system' was the only practice in which teachers had disagreements: for some it was clearly related to corruption (sending private tutees to each other to generate income), while for others it was just a tool for recommending good teachers to parents without any material benefit. 


\section{Regulating private tutoring}

Only half of the interviewed teachers have heard of the Teachers' Code of Ethics, which discourages teachers from tutoring their students. Among them, only two have read it. This indicates a lack of information regarding professional regulations, especially in rural areas. All the interviewed teachers agreed that although the recommendation may seem morally correct, it is not a feasible suggestion to teachers in their given socio-economic situation, particularly in rural schools. The following comment that one teacher made, was typical:

There are not many choices for teachers in small towns and villages. It is difficult and costly for students to travel to another village or town. Therefore, students have to receive tutoring from their own teacher (Teacher $\mathrm{O}$ ).

The lack of tutors in small villages was named as a common reason that makes the recommendation irrelevant. Teacher $\mathrm{B}$ pointed out the relativistic nature of the recommendation: "Whether it is a workable code depends where you live - in a city or in a village. This is why it is a recommendation, so it gives flexibility to teachers".

The further query on why urban schoolteachers who have bigger choices of private students still tutor their students appeared tricky to almost all teachers. Some of the teachers interviewed kept silent for a couple of minutes. This silence showed that urban-rural difference is not the only reason why the recommendation seemed irrelevant in the Georgian context. Their comments disclosed teachers' mixed feelings about the issue. At the beginning of the interviews, the teachers mostly sounded like they treated the issue of tutoring their students as unproblematic; later, however, most of them changed their minds or showed ambivalent attitudes. Teacher L from Tbilisi with quite large numbers of private students remarked, "That's [the code] still a recommendation. When it becomes a law, I will follow it. But why is it a problem?” After a couple of minutes of talking on this issue, this teacher confessed that sometimes she has guilty feelings from tutoring her students.

It is noteworthy to mention that regardless of whether teachers had heard of the Teachers' Code of Ethics, all of them explicitly or implicitly indicated that tutoring their students is a questionable practice. This is part of an internal knowledge of and feelings about teacher professional ethics. Some of them verbalised this attitude as follows, "I know, I should not tutor my own student", "this is a conflict of interest", "it brings discomfort to me", "tutoring one's own student includes a shadowy aspect", "it is humiliating to me that I have no other choice", and "I hate seeing my student in school whom I talked about money at home" (Teacher E).

Some schools in Georgia initiated school-level policies and regulations, which discourage or even prohibit teachers from tutoring their students. One rural schoolteacher related the story of her own school:

In the beginning of a school year, the school administration told us teachers that we should refrain from tutoring our own students...but we still tutored our students, sometimes openly and sometimes secretly.

Some schools even initiated written prohibitions. One teacher from a regional town recalled that although she signed the paper, she never followed the regulation. Nobody made any effort to monitor the regulation either.

\section{Future directions about regulations}

In general, the teachers agreed that the prohibition of tutoring would not work in Georgia given teachers' low salaries. One teacher from Tbilisi emotionally expressed:

Prohibition? Oh, it will be a revolution! What keeps a teacher in school is private tutoring! A student needs tutoring, I need tutoring and the school needs tutoring. Otherwise, I would say goodbye to the school and find a different job!

Many teachers related regulations of tutoring to teachers' low salaries. "When teacher salaries rise, tutoring will shrink in scale”, Teacher $\mathrm{H}$ commented. In contrast, some of the 
interviewed teachers said that the country could never get rid of private tutoring even with higher teachers' salaries, because the practice is ingrained in culture.

Although there was a general negative attitude towards the regulations, some teachers were sympathetic. For example, one teacher talked about regulating the quality of tutoring: "Tutoring should be regulated somehow... For example, teachers should obtain a license. Not everyone should have the right to engage in tutoring because of the quality...” (Teacher D).

Two participants reported that some schoolteachers tried to rent apartments to conduct large class tutoring. Teachers were very negative of such commercialisation of private practice, as one commented: "Prohibition will not work, but opening schools at homes is also unacceptable" (Teacher A). As an alternative for regulations, teachers talked about extended school hours, shortening curriculum and most importantly, raising teacher salaries.

\section{Discussion and conclusions}

The findings of this study resonate with other research reported in different parts of the world and enrich our understanding of teacher corruption in the case of post-Soviet Georgia. Data from teacher interviews demonstrate how teacher-student negotiation for education in the unregulated tutoring market increases the risks of corruption, which can lead to eroding professional credibility of teachers and, in a broader sense, undermine public trust in the education system. The findings also suggest that in order to define teacher corruption, we need to see how it operates in a given cultural context. Understanding the local context and cultural logic is useful and a requisite before labelling a practice as 'teacher corruption'. Although there are some universalistic aspects of corruption that are widely recognised, there are many cultural nuances and particular ways of thinking, which influence how people recognise and respond to corruption practices in different societies.

The Georgian teachers rely heavily on income from two sources: regular schools and private tutoring. These two sources are interdependent for at least three reasons, which perhaps prevent teachers' exodus from schools into the tutoring business. Firstly, supplemental income from tutoring is temporary, while salaries from government schools are stable during an academic year, including holidays. Secondly, a teaching job in schools gives legitimacy to teachers to be tutors. Moreover, evidence suggests that teachers need to teach in schools in order to attract private students. Lastly, commercial private tutoring, which would compete with schools for the best teachers, is not (yet) developed in the country.

The previous literature on teacher corruption mainly discussed teacher-initiated corruption performed through various coercive mechanisms, such as overemphasising the need for tutoring through marketing tricks. However, a distinction has not been made between teacher-initiated (provider-initiated) and student and parent-initiated (client-initiated) forms of corruption. Literature on political corruption has discussed orientations and directions of corruption and their roles in corruption controlling methods (see e.g. Karklins, 2005; Miller, Grodeland \& Koshechkina, 2011). Exploring the Georgian teachers' perspectives on tutoring provided a more nuanced understanding of teacher corruption. Teachers recalled situations when parents purposefully sent children to their teachers with the expectation of coveted benefits, such as exam answers. These cases show the pervasiveness of corruption in the education system on deeper levels. They also demonstrate how corruption in education has a long-term impact as it distorts ethical and moral values of young people in the course of schooling (Bray \& Kwo, 2014, p. 31).

The findings from teachers' interviews provided insights into the structure of social reality in Georgia, particularly showcasing strong social networks of obligation, leading to favoritism. When teachers inflate marks in exchange for monetary gain, such behavior is publicly considered unethical. However, friendship ties change that perception, rendering tutoring as a moral responsibility. This type of 'responsibility' echoes what Granovetter (2004) called "a norm of reciprocity", which regulates gift and favor exchange among individuals (p. 154). 
As shown in the findings section, the Georgian teachers are poorly paid despite their status in society. Private tutoring for them is a survival strategy (Rose-Ackerman, 1999). In education systems with low teacher pay, weak accountability system, and lack of monitoring teacher efficacy, teachers take advantage of the opportunity to generate additional income from tutoring. Milovanovitch (2013, p.235) remarked that corruption temptation might exist even in the best of education systems, because it is "an opportunistic behaviour invited by windows of opportunity created by weak monitoring and control”.

In line with Bray's (2013) findings, this study has shown that corruption risks are associated not only with tutoring one's own students, but also with the entire system of teacher-provided tutoring. The diagram in Figure 2, culled from the interview data, indicates the corruption risks associated with different forms of teacher-provided tutoring, i.e., provided by the students' own teacher, by another teacher from the same school, or by a teacher from a different school.

[Insert figure 2 here]

Teacher-provided tutoring is widely accepted and normalised in Georgian society. Teachers' tutoring of their students is not necessarily a form of corruption. However, it includes a high risk of corruption, which needs some types of actions. Prohibiting teachers to tutor their students would not work and would lead to 'a revolution', as noted by one of the teachers. Teacher's tutoring of their students is especially inevitable in rural areas, where there is a shortage of available teachers and choosing a tutor from another school would require extra transportation costs and would increase households' spending on tutoring. This echoes similar patterns in Central Asian countries (Kazakhstan, Kyrgyzstan and Tajikistan) where small towns and rural areas experience a lack of available tutors (Silova, 2009, p.87). The data from this study confirmed that 'punitive approaches' (Heyneman, 2011; Meir et al., 2013) are less likely to be an appropriate policy choice in Georgia.

Teachers' tutoring of students is not corruption per se for another reason: it does not always involve fee-based tutoring. As this and other studies have demonstrated, free tutoring is an integral part of the Georgian school culture. Free tutoring is not a phenomenon that is unique to the Georgian context, but is also widely found elsewhere (see e.g. Bray, 2009; Bray \& Kwo, 2014, p. 6). The metaphor of Robin Hood Teachers used earlier in this paper refers to teachers' perceptions of tutoring their students in the context when they charge some students fees, but 'redeem' their guilty feelings by tutoring others for free. Teachers purposefully mix 'free students' with fee-paying students in groups, so that the latter covers expenses of tutoring for the whole class.

This study has also highlighted the importance of the governmental role, which allocates salaries and monitors teacher performance. The findings have revealed that not all teachers are informed that a Teacher Professional Code of Ethics exists. Thus, a proper education process is necessary to inform teachers of the explicit ethical guidelines, which may prevent some forms of teacher misconduct. The most considerable issues are how to contain teacher corruption by implementing effective mechanisms of accountability to ensure a corruptionfree education system. Bray (2013, p.85) stressed the importance of public campaigns where different stakeholders of education would act as whistle-blowers. The EFA Global Monitoring Report (UNESCO, 2014, p.38) called on governments to improve teacher governance and at the same time ensure appropriate teacher pay so that teachers earn "at least enough to lift their families above the poverty line and make their pay competitive with comparable professions". Collaborations of educational civil society organisations at the national level with a network of international organisations can be another way to develop an effective anti-corruption policy agenda in education (Martinez \& McNair, 2013). To incentivise anti-corruption actions, Transparency International (2013, p.xxii) emphasised the need for new methods to teach ethics to students and also highlighted the role of cooperative agreements between parent groups and school management, such as "integrity pledges”. 
The complexity of teacher corruption needs further scrutiny. Any case of teacher corruption, as well as any form of corruption in education, is detrimental to the education system as it deteriorates the quality of education and imparts to young students unethical cultural values (Rymiantseva, 2005). Teacher corruption can undermine the work of honest teachers not involved in corruption, which, in turn, can encourage the teacher deprofessionalisation process from the loss of public trust in the teaching profession nationwide. Irrespective of the degree of corruption, the quality of public education suffers from the lack of teacher investment in and commitment to public education. Teacher corruption incidences place the entire education system at risk as it damages the social role and function of the school in promoting good citizenship. Lastly, the loss of trust in the education system "may become a threat to national and social cohesion" (Silova, Johnson \& Heyneman, 2007, p. 175).

\section{Notes}

1. 'Revolution of Roses' refers to a change of political power in Georgia on November 23, 2003 when, after massive street protests, President E. Shevardnadze was forced to resign.

2. While 23 years have passed since the break-up of the Soviet Union, its legacy largely defines contemporary life and policies in Georgia. I describe the general background of teacher profession in Georgia in the post-Soviet context because a significant portion of teachers has the Soviet background and many of them taught during the Soviet times. Perceptions about teacher profession are in many ways informed by the memories and myths about the Soviet Union.

3. The subsistence level is calculated based on the minimum food basket defined by the Ministry of Health, Labour and Social Affairs of Georgia. For example, in 2005 the subsistence level for an average family was 160.3 GEL ( US\$90), while a teacher’s basic salary was 115 GEL ( US\$65) (GeoStat, 2014; MoES, 2013).

4. For example, in 2012-2013 academic years, female teachers comprised 85 percent of total teaching force (GeoStat, 2014).

5. Tutoring provided by the teachers usually takes place in teachers' homes. Teachers used terms like "teaching at school" and "teaching at home" to differentiate between school and private tutoring.

6. The term "Robin Hood Teachers" was coined by Professor Roger Dale during my discussion with him about this phenomenon in Georgia on May 8, 2014.

7. Given the sensitivity of the topic, third person accounts in the interviews mostly served as a mechanism to anonymise teachers' identity. I observed that in this case, participant teachers felt more secure and data confidentiality was better guaranteed.

\section{References}

Alatas, S. H. (1968). The sociology of corruption: The nature, function, causes and prevention of corruption. Singapore: Donald Moore Press.

Barret, D. (2014, April 28). Expensive gifts for teachers raises spectre of classroom corruption. The Telegraph, p.1. Retrieved from http://www.telegraph.co.uk/education/educationnews/10791169/Expensive-gifts-forteachers-raises-spectre-of-classroom-corruption.html

Berg, B. (2009). Qualitative research methods for the social sciences $\left(7^{\text {th }}\right.$ ed.). Boston, MA: Allynand Bacon.

Bernard, H. R. (1988). Research methods in cultural anthropology. Newbury Park: Sage.

Bernard, H. R. \& Ryan, G. W. (2010). Analyzing qualitative data: Systematic approaches. Thousand Oaks, CA: Sage.

Biswal, B. (1999). Private tutoring and public corruption: A cost effective education for developing countries. The Developing Economies, 37, 222-40.

Bray, M. (2003). Adverse effect of private supplementary tutoring: Dimensions, implications and government responses. Paris: UNESCO International Institute for Educational Planning (IIEP). 
Bray, M. (2009). Confronting the shadow education system: What government policies for what private tutoring?Paris: UNESCO International Institute for Educational Planning (IIEP).

Bray, M. (2013). Shadow education: The rise of private tutoring and associated corruption risks. In G. Sweeney, K. Despota, \& S. Lindner (Eds.), Global corruption report: Education (pp. 83-87). Oxon and New York, NY: Routledge.

Bray, M., \& Kwo, O. (2014) Regulating private tutoring for public good: Policy options for supplementary education in Asia. Hong Kong: Comparative Education Research Centre (CERC) and UNESCO.

Brehm, W., Silova, I., \& Tuot, M. (2012) Hidden privatization of public education in Cambodia: The impact and implications of private tutoring (Education Support Programme Working Paper Series 29). Budapest: Open Society Foundations.

Central Intelligence Agency. (2013). World Factbook. Retrieved from https://www.cia.gov/library/publications/the-world-factbook/geos/gg.html

Creswell, J. (2007). Qualitative inquiry and research design: Choosing among five approaches (3rd ed.). Thousand Oaks, CA: Sage.

Dawson, W. (2009). The tricks of the teacher: Shadow education and corruption in Cambodia. In S. P. Heyneman (Ed.), Buying your way into heaven: Education and corruption in international perspective (pp. 51-74). Rotterdam: Sense.

Gabedava, M. (2013). Reforming the university admission system in Georgia. In G. Sweeney, K. Despota, \& S. Lindner (Eds.), Global corruption report: Education (pp. 155-160). Oxon and New York, NY: Routledge.

GeoStat. (2014). Household Income [Statistical report]. National Statistics Office of Georgia, Tbilisi. [In Georgian]. Retrieved from http://geostat.ge/?action=page\&p_id=205\&lang=geo

Ginsburg, M. B., \& Megahed, N. M. (2009). Comparative perspectives on teachers, teaching and professionalism. In L. J. Saha, A. G. Dworkin (Eds.), International Handbook of Research on Teachers and Teaching (pp. 539-556). Springer Science+Business Media.

Global Edge. (2013). Georgia: Economy. Retrieved from http://globaledge.msu.edu/countries/georgia/economy

Granovetter, M. (2004). Social construction of corruption. Paper presented at The norms, beliefs and institutions of 21st century capitalism: Celebrating the 100th Anniversary of Max Weber's "The protestant ethic and the spirit of capitalism" Conference, Cornell University, USA. Retrieved from http://iis-db.stanford.edu/evnts/4117/The_Social_Construction_of_Corruption_Oct04.pdf

Heidenheimer, A. (1970). Political corruption: Readings in comparative analysis. New Brunswick: Transaction Books.

Heyneman, S. P. (2011). Private tutoring and social cohesion. Peabody Journal of Education, 86, 183-188.

Institute for Social Studies and Analysis [ISSA]. (2008). Study on teacher supply and demand. Tbilisi: Teacher Professional Development Center [in Georgian].

Institute for Social Studies and Analysis [ISSA]. (2012). Study on teacher attitudes toward professional development scheme. Tbilisi: Teacher Professional Development Center [in Georgian].

International Institute of Education Policy, Planning and Management [EPPM]. (2011). Study of private tutoring in Georgia. Tbilisi: EPPM. [In Georgian].

Johnson, E. (2008). Out of control? Patterns of teacher corruption in Kyrgyzstan and their implications for the study of street-level corruption control. (Unpublished doctoral thesis). Teachers College, Columbia University, New York.

Karklins, R. (2005). The system made me do it: Corruption in post-Communist societies. Armonk, NY: M.E. Sharpe.

Klugman, J., Micklewright, J., \& Redmond, G. (2001). Fighting poverty in transition: Social expenditures and the working- age poor. Florence: UNICEF Innocenti Research Centre. 
Ko, K., Cho, S. Y. \& Lee, J. (2012) The trend of the tolerance of gray corruption and its determinants: Citizens' perception in Korea. Paper presented at the 2012 International Public Management Network Conference, Hawaii, USA.

Kobakhidze, M. N. (2013). Teacher certification examinations in Georgia: Outcomes and policy implications. In M. Akiba (Ed.), Teacher reforms around the world: Implementations and outcomes (International Perspectives on Education and Society, Vol. 19, pp. 25-51). Bingley: Emerald Books.

Kostadinova, T. (2012). Political corruption in Eastern Europe: Politics after Communism. Boulder, CO: Lynne Rienner.

Larmour, P. (2008). Corruption and the concept of 'Culture': Evidence from the Pacific Islands. Crime, Law and Social Change, 49, 225-239.

Ledeneva, A. (2009). Corruption in postcommunist societies in Europe: A re-examination. Perspectives on European Politics and Society, 10 (1), 69-86.

MacWilliams, B. (2002, August 12). In Georgia, Professors Hand Out Price Lists. The Chronicle of Higher Education. Retrieved from http://chronicle.com/weekly/v48/i47/47a03401.htm

Martinez, E., \& McNair, D. (2013). Sharing knowledge, sharing power: fighting corruption in education across the globe. In G. Sweeney, K. Despota, \& S. Lindner (Eds.), Global corruption report: Education (pp. 315-320). Oxon and New York, NY: Routledge.

Matiashvili, A., \& Kutateladze, N. (2006). Georgia. In I. Silova, V. Būdienė, \& M. Bray (Eds.), Education in a hidden marketplace: Monitoring of private tutoring (pp. 191-210). New York: Open Society Institute.

Meir, B., \& Friedrich Ebert Foundation. (2013). Service providers or power brokers: the pivotal role of teachers for educational integrity. In G. Sweeney, K. Despota, \& S. Lindner (Eds.), Global Corruption Report: Education (pp. 68-69). Oxon and New York, NY: Routledge.

Miller, W., Grodeland, A., \& Koshechkina, T. (2001). A culture of corruption? Coping with government in post-Communist Europe. Budapest: Central European University Press. Ministry of Education and Science of Georgia [MoES]. (2013, January 29). Ministers decree $\# 04 / \mathrm{N}$ on teacher salaries and working conditions. [in Georgian].

National Center for Teacher Professional Development. (2010). Teacher professional code of ethics. Tbilisi: TPDC. [in Georgian].

Ngwe, G (2013). Teacher absenteeism in primary schools in Cameroon. In G. Sweeney, K. Despota, \& S. Lindner (Eds.), Global corruption report: Education (pp. 74-78). Oxon and New York, NY: Routledge.

Nowak, R. (1996). Corruption and transition economies. Geneva: Economics Analysis Division, United Nations Economic Commission for Europe (UNCE). Retrieved from http://www.unece.org/fileadmin/DAM/trans/osce/osceunece/misc_corruption.pdf

Patrinos, H. A. (2013). The hidden cost of corruption: teacher absenteeism and loss in schools. In. Global Corruption Report: Education (pp. 70-73). Oxon and New York, NY: Routledge.

Popa, S. (2007) Defensible spaces: Ideologies of professionalism and teachers' work in the Romanian private tutoring system. (Unpublished doctoral thesis). University of Pittsburg.

Rose-Ackerman, S. (1999). Corruption and government: Causes, consequences, and reform. Cambridge: Cambridge University Press. Rothstein, B., \& Torsello, D. (2013). Is corruption understood differently in different cultures? Anthropology meets Political Science (Working Paper Series 5). University of Gothenburg: The Quality of Government Institute, Department of Political Science.

Silova, I. (2009). Private supplementary tutoring in Central Asia: New opportunities and burdens. Paris: UNESCO, International Institute for Educational Planning.

Silova, I., Būdienè, V., \& Bray, M. (Eds.). (2006). Education in a hidden market place: Monitoring of private tutoring. Budapest: Education Support Program (ESP) of the Open Society Institute.

Silova, I., Johnson, M. S., \& Heyneman, S. P. (2007). Education and the crisis of social cohesion in Azerbaijan and Central Asia. Comparative Education Review, 51, 159-180. 
Soldo, A., \& Jokić, B. (2013). The role of teachers in the decision concerning use of private tutoring services. In B. Jokić (Ed.), Emerging from the shadow: A comparative qualitative exploration of private tutoring in Eurasia (pp. 117-162) Zagreb: Network of Education Policy Centers.

Temple, P., \& Petrov, G. (2004). Corruption in higher education: Some findings from the states of the former Soviet Union. Higher education management and policy, 16, 83-100.

Transparency International (2013). Executive summary. In G. Sweeney, K. Despota, \& S. Lindner (Eds.), Global corruption report: Education (pp. xix-1). Oxon and New York, NY: Routledge.

Transparency International Bosnia and Herzegovina (2013).Understanding experiences and perceptions of corruption inhigher education in Bosnia and Herzegovina. In G. Sweeney, K. Despota, \& S. Lindner (Eds.), Global corruption report: Education (pp. 189 -193). Oxon and New York, NY: Routledge.

Tsakonas, F., 2002. Private sector development in education in South East Europe: Country report: Albania. Washington, DC: World Bank.

UNESCO. (2014). Teaching and learning: Achieving quality for all (EFA Global Monitoring Report). Paris: UNESCO.

Wan, W. (2013, October 7). In China, parents bribe to get students into top schools, despite campaign against corruption. Washington Post, p.1. Retrieved from

http://www.washingtonpost.com/world/in-china-parents-bribe-to-get-students-into-topschools-despite-campaign-against-corruption/2013/10/07/fa8d9d32-2a61-11e3-8adea1f23cda135e_story.html

World Bank. (2001). Project appraisal document on the first phase of the proposed adaptable program credit (Report No: 20952-GE). Washington, DC: Author. Retrieved from http://www.worldbank.org/en/country/georgia/projects/all

World Bank. (2012a). Fighting corruption in public services: Chronicling Georgia's reforms. Washington, DC: Author.

World Bank. (2012b).Implementation completion and results report (Report No: ICR2024). Washington, DC: Author. Retrieved from http://web.worldbank.org/external/projects/main?pagePK=51351038\&piPK=51351152\&t heSitePK=40941\&projid=P055173.

Yang, K. (2012, November 28). Corruption in schools must be stopped. South China Monitoring Post, p. 1. Retrieved from:

http://www.scmp.com/comment/insight-opinion/article/1092324/corruption-schoolsmust-be-stopped. 
Figure 1. Continuum model of teacher corruption

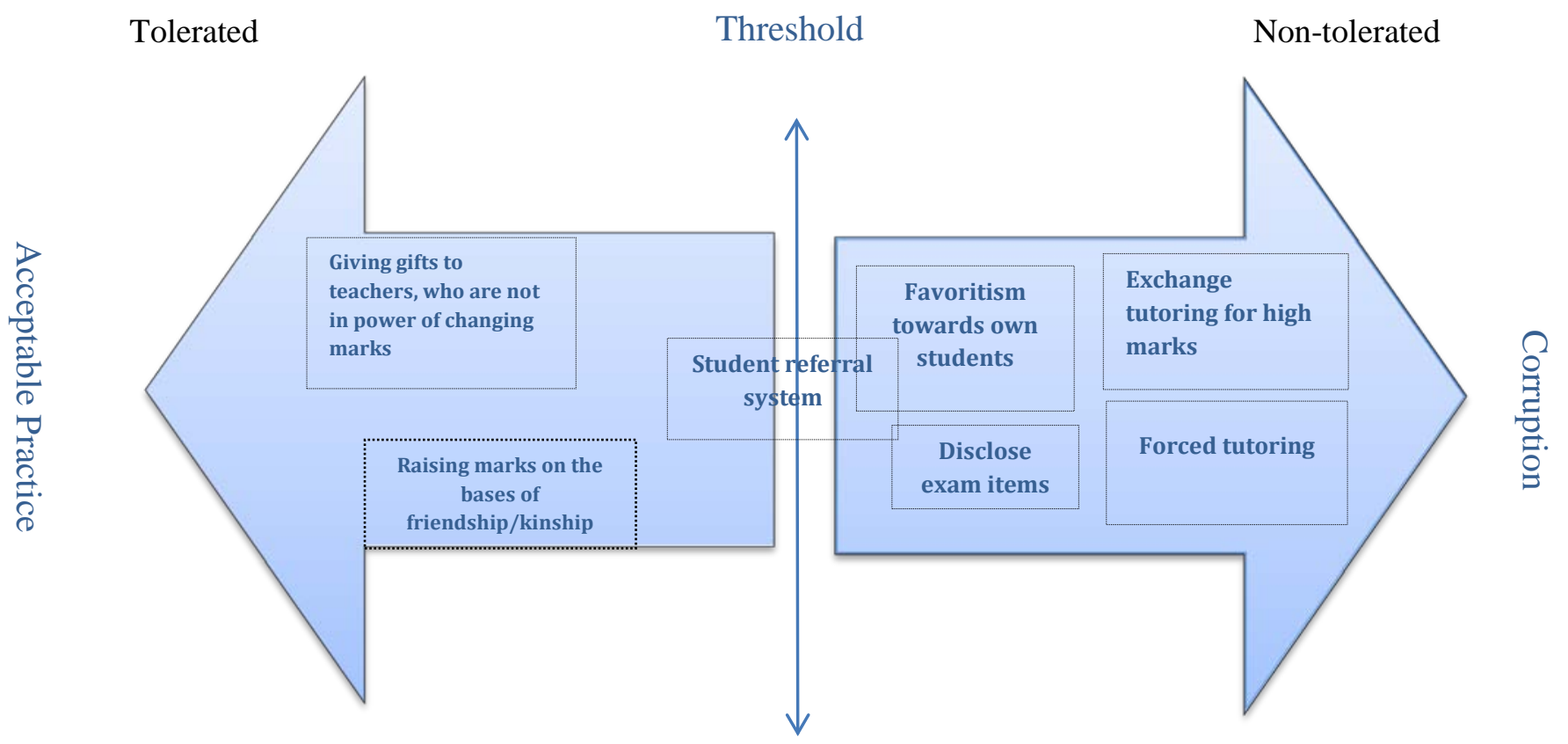


Figure 2. Teacher-supplied tutoring and associated corruption risks

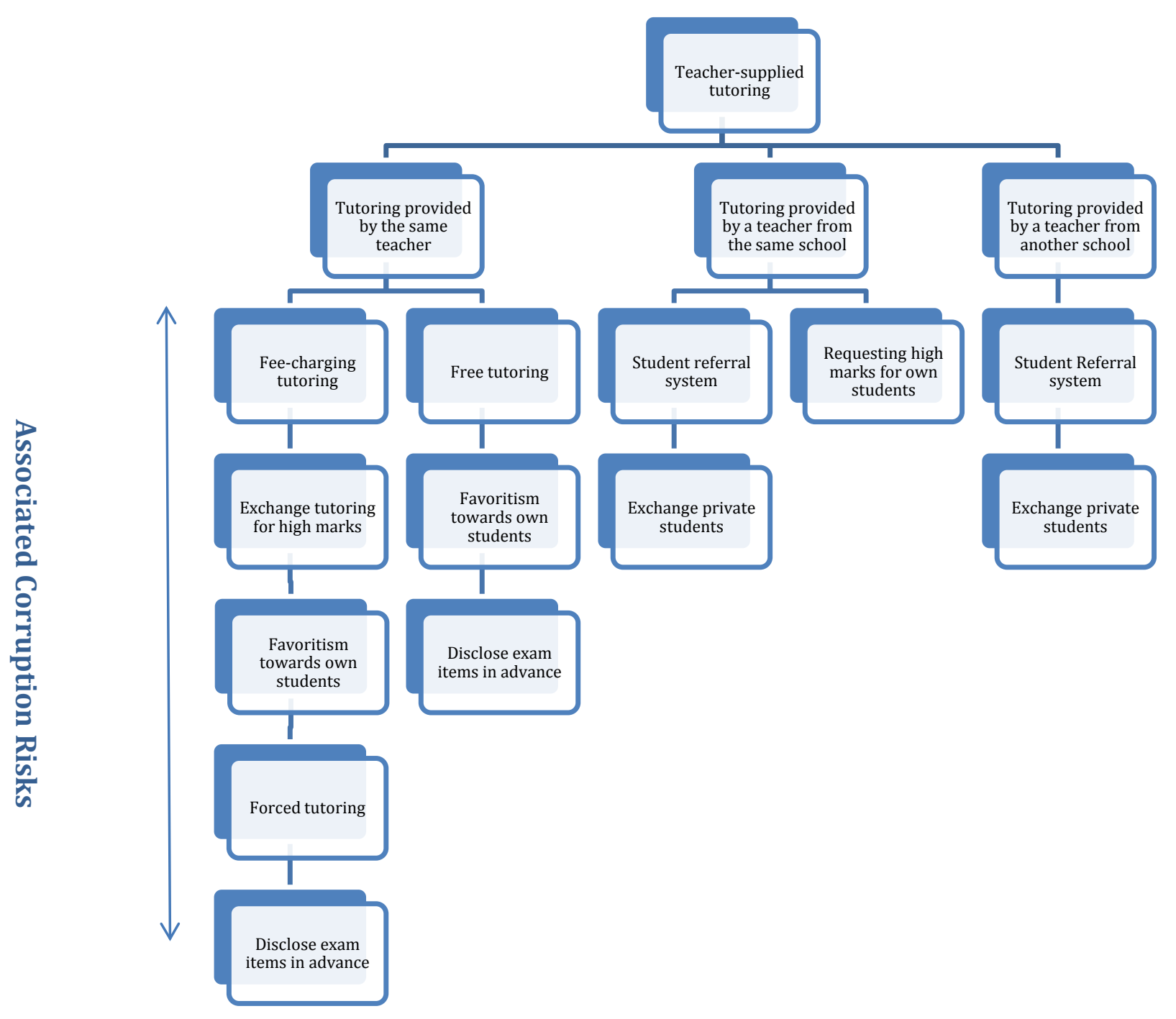

